\title{
Factors Affecting the Purchase Decision of Investors in the Residential Property
}

\section{Market in Malaysia}

\author{
Saw Lip Sean ${ }^{1} \&$ *Tan Teck Hong ${ }^{2}$ \\ ${ }^{2}$ Henley Business School, University of Reading, Malaysia. \\ *teck-hong.tan@ reading.ac.uk / teck-hong.tan@henley.edu.my
}

\begin{abstract}
The objective of the paper is to determine the key factors that investors consider before making an investment decision to purchase a residential property. In this study, 200 self-administered questionnaires were distributed to respondents who have obtained or transacted more than one (1) residential property for the past three years. Only 105 survey forms were returned and used in generating the analysis. Locational, neighborhood, structural and financial factors were taken into consideration in this survey. The results revealed that locational, financial and structural factors do affect property investors in making their purchases. By understanding the motivation behind purchasing residential properties, investors would be able to gauge the factors that matter most before investing in property.
\end{abstract}

Keywords: investors, residential property market, property financing, Malaysia

\section{INTRODUCTION}

Over the recent years, there has been an ever-increasing price increment in the Malaysian property market. According to Chin (2013), the property price in Malaysia is on its all-time high, resulting in difficulties even for young home buyers and growing families to afford to own property, even more so for the low-income group. There are three (3) key players in the property market, namely investors, speculators, and homeowners. Investors purchase property in hopes of generating financial returns and they look into rental yields as well as capital appreciation. Speculators are those who enter the market for a short span, expecting to make huge capital profits. Lastly, homeowner refers to those who purchase properties for their own dwelling.

The appreciation of house values has created a good opportunity for investors to purchase a property as a form of investment in order to multiply their wealth creation capabilities. There are two types of potential returns from buying a property, namely rental payment and capital gain from increasing value in property. Tan (2008) stated house buyers believe they will gain a profitable amount of return through rental income and capital growth and it is proven that buying a property is a good form of investment to hedge against inflation.

The property market is affected not only by the local property investors, but also international and regional property investors. According to The Edge (2013), Malaysia is seen as an emerging property market among foreign investors. Due to the recent government policies and good economic growth, numerous property investors from foreign countries are now looking into Malaysia as a lucrative property market to invest in. According to Mira (2013), Malaysia has an edge in property ownership regulations that are relaxed and foreign investor-friendly as compared to countries like Singapore and Indonesia, which have many control measures to limit foreign investments. The Malaysian government has also developed the Malaysia My Second Home (MM2H) scheme to attract foreigners 
residing in Malaysia. In Malaysia, foreigners are allowed to purchase freehold properties and pay a lower stamp duty rate as compare to neighboring countries. According to Yoong (2012), the MM2H program has brought in 17,389 foreigners from the year 2002 to 2011, mainly from China, Singapore, Britain and Iran.

There has been a limited number of housing studies on the Malaysian property investors' point of view. Previous researches often only consider the general homeowner's perspective; therefore, the purpose of this research is to provide rare insights into understanding the factors behind the investor's preference to invest in residential properties in Malaysia. According to Daly et al. (2003), a better understanding and prediction of decision making in the real estate markets would be accomplished when there is a better knowledge of factors that would influence property-buying behaviour. Furthermore, this research would identify the characteristics of the residential property investors in Malaysia. Also, this paper would be essential for investors, developers, financial planners, mortgage bankers as well as real estate agents for a better understanding in the decision-making of investors when purchasing residential properties.

\section{LITERATURE REVIEWS}

According to Haughwout et al. (2011), the definition of an "investor" is that of a property buyer with residential property portfolio consisting of multiple properties, and does not live in all of them. There are several reasons that motivate investors in property investment. Seelig (2009) and Tan (2009) stated that almost all of the investors report high rates of satisfaction and have a feeling of 'success' in terms of receiving capital appreciation and good rental yields. Through property investment, investors could earn either passive income from collecting rents or property value appreciation over time (Hutchison, 1994). However, some property purchasers consider capital gains rather than rental income as a motivator for investing in a property, in regardless of whether they own only one home or many units at one time (Case \& Shiller, 1988). Furthermore, a property is proved to be an investment instrument to hedge against inflation as compared to other types of assets (Fama \& Schwert, 1977).

The next question that lies ahead for an investor is that what are the factors that would lead an investor in the decision-making process to purchase a residential property? This paper uses a summary of existing variables identified previously, such as locational, neighborhood and structural attributes as well as the financial variable.

\section{LOCATIONAL FACTORS}

Good locational attributes are generally linked to the proximity and accessibility towards local amenities such as school, shopping malls and transportation centers (Clark et al., 2006; Kauko, 2007: Levine, 1998; Tan, 2011b). Elder and Zumpano (1991) argued that the price of land and house is reflected in good locations or areas that are near to schools, shopping centre and public transports. Daly et al. (2003) claimed that location has a major impact on buyer's preference in purchasing residential properties in Australia, UK and Ireland. Distance is described as a factor that affects buyer's preference in the decision making of property buyers, such as distance to workplace, schools, shops and central business districts (CBD). The distance to home from workplace is largely considered when choosing a property to invest in. Karsten (2007) and Tu and Goldfinch (1996) stated that the distance from the workplace has been found to affect household choice among residents preferring not to spend too much time travelling to work. Furthermore, Kauko (2003) identified that location has a strong correlation with the increment of property value and behaviours in property investment. 


\section{NEIGHBOURHOOD FACTORS}

Choguill (2008) defined neighborhood as a space in which residents live together for a common interest. As stated by Tan (2011a), a home that is situated in a good neighborhood would be preferable as households are willing to pay more for the house with good indoor and outdoor environmental qualities. Studies by Chapman and Lombard (2006) and Tan (2011a) stated that neighborhood environment, such as cleanliness, pollution and crime are important factors before deciding on the purchase of a property.

It is of prime importance that safety in the neighborhood is the main concern for property purchasers in Malaysia nowadays due to an increase in the trend of crimes such as burglary and snatch thefts. According to Hunter (1985) and Lang and LeFurgy (2007), homeowners are willing to pay more to live in a gated and guarded neighborhood to attain a greater peace of mind. Similarly, investors would have to look into the property in the gated and guarded neighborhood in order to make sure they are getting the most for their investment. Gated-guarded properties usually come with a price tag. Asiedu and Arku (2009) mentioned that with CCTV installed along the fences and security personnel guarding the vicinity would bear greater costs associated with the maintenance of the gated guarded property. Additionally, there is a common perception among people that a gated and guarded housing estate reflects an individual's ranking or income (Blakely \& Snyder, 1998; Tan, 2010a). People choose to live in a gated and guarded community for the elite image that is projects along with the desire for differentiation. This is because the gated and guarded community is said to symbolise and crate ranking on the social ladder.

\section{STRUCTURAL FACTORS}

Structural attribute considers all physical conditions as well as the quality of the property. The number of rooms or bathrooms in a house is a feature that one considers before making home-ownership decisions, particularly in western countries (Hurtubia et al., 2010). Common structural attributes consist of size of living hall and dining hall, built-up size, and number of bedrooms and bathrooms (Arimah, 1992; Fierro et al., 2009; Laakso \& Loikkanen, 1995; Tan, 2012b; Tiwari \& Parikh, 1998; Tse \& Love, 2000; Wilhelmsson, 2000). It is generally believed that buying a property for own use and buying an investment property has different criteria. Investors generally prefer smaller properties especially apartments and flats because these properties have always been more popular among tenants (Kohler, 2013).

\section{FINANCIAL FACTORS}

The financial attribute is also taken into consideration by property investors. As mentioned by Reed and Mills (2006), several key areas regarding the financials are identified. These include mortgage interest rates, household income, house price, and ability to obtain financing. As an investor, the financials might be the utmost important factor among all factors. This is because the financials are often involved with money in which investors would want to gain from their investment. In the case of homeowners, the financials accounts almost 30 percent of the decision for them when purchasing a house (Reed \& Mills, 2006).

In Malaysia, the ability to obtain financing has now been stricter since January 2010. It is because the housing loan eligibility must now be based on net income rather than gross income. Also the Central Bank of Malaysia has lowered the loan-to-value (LTV) ratio to $70 \%$ for the third property onwards. As such, investors now may find it harder to obtain financing and it may dampen their ability to 
purchase more residential properties. Karsten (2007) mentioned that affordability is a major factor in terms of making purchasing decisions of a residential property. Therefore, the financial factors would play a significant role in making investment decisions.

In the recent Malaysian Budget 2014, the government has taken certain cooling measures to curb speculative activities in the housing market. The recent budget has announced the increase in the rate of property speculation tax, known as Real Property Gains Tax (RPGT) with effect from 1 Jan 2013. There is a $30 \%$ RPGT for properties sold within 3 years of ownership, followed by $20 \%$ in $4^{\text {th }}$ year and $15 \%$ in $5^{\text {th }}$ year, respectively. According to Lim (2013), the upward revision on the RPGT would affect the property market in the short run and it decreases property purchasers to speculate in the long run. Additionally, the recent government budget has also imposed curbs on the Developer Interest Bearing Scheme (DIBS). DIBS has become a popular and easy financing package offered in joint-promotion activities between banks and developers in recent years as the scheme allows a low barrier to entry for property purchases, enabling property buyers to purchase without having to make any payment until the property is fully constructed. Property investors would have to pay interest on the project that they invested into now due to the effect of this abolishment. Interest rates, such as the base lending rate (BLR) are directly correlated with the housing market as the sensitivity of change in interest rates may affect the demand for properties (Tan, 2010b).

Based on the previous discussion, several hypotheses were formulated as follows:

\section{$H_{1}$ : Locational factors affect the investor preference in purchasing residential properties in Malaysia.}
$\mathrm{H}_{2}$ : Neighborhood factors affect the investor preference in purchasing residential properties in Malaysia.

$H_{3}:$ Structural attributes of housing affect the investor preference in purchasing residential properties in Malaysia.

\section{$H_{4}:$ Financial factors affect the investor preference in purchasing residential properties in Malaysia.}

\section{METHODOLOGY}

\section{METHODS OF SURVEY AND SAMPLING}

In this study, self-administered questionnaire using a 5-point Likert scale was used to collect the data from the respondents from Greater Kuala Lumpur (GKL), Malaysia. GKL was recognized as the vital economic growth center as over $37 \%$ of the nation's gross national product is known as being associated to Kuala Lumpur and Selangor (Tan \& Phang, 2014). To ensure the validity of the responses, respondents were selected based on the criteria that they should have obtained or transacted more than one (1) residential property for the past three years. The preliminary questions in the survey, namely "Do you invest in residential properties?" "Is your motive of purchasing the property a profit making decision?" were designed to identify "investors". These self-administered questionnaires would be distributed to any respondent who fits the criteria of an investor.

The questionnaires were distributed through one of property investment clubs as they have a large number of property investors to be approached upon. Of 200 copies of questionnaire forms were 
being distributed, only 105 forms were returned (the response rate of 52.5 percent). The dependent variable of this study was the motivation of investing in properties and the four factors, namely locational, neighborhood, structural, and financial factors are the explanatory variables. These survey instruments were guided by previous studies with slight modifications from the works of Tan (2011a), Tan (2012a), Wilhelmsson (2000), Tse and Love (2000) and Reed and Mills (2006).

\section{STATISTICAL ANALYSIS}

A descriptive analysis was performed to explore the data related to the demographic characteristics of investors. Tables were used to interpret the demographic profiles of investors. Next, the factor analysis is conducted to identify the validity of the constructs. Factors with the eigenvalues of more than 1 were used to perform the analysis. Variables with a factor loading of less than 0.4 were deleted from the data. Varimax rotation was used to group survey items that are related into one single factor. Subsequently, a reliability test (Cronbach's alpha) is performed to test the strength of these constructs. All the survey items with the same underlying pattern were grouped together to construct an index. In this study, five composite indexes were used to determine the effect of locational, neighborhood, structural and financial attributes on the motivation of property investment.

Lastly, regression analysis was used to identify the relationship of these constructs. An explanation of the multiple linear regression models that is expected to be constructed can be given as follows:

where:

$$
M_{i}=\beta_{0}+\beta_{1} L_{i}+\beta_{2} N_{i}+\beta_{3} S_{i}+\beta_{4} F_{i}+\varepsilon_{i}
$$

$M=$ Motivation of property investment

$L=$ Locational factors

$N=$ Neighborhood factors

$S=$ Structural attributes of housing

$F=$ Financial factors

$\varepsilon=$ Error term for $M$

$\beta_{0,}=$ Intercept for $M$

$\beta_{1,} \beta_{2}, \beta_{3}, \beta_{4}=$ Coefficients to be estimated

\section{RESULTS AND DISCUSSIONS}

\section{DESCRIPTIVE ANALYSIS}

Of 105 respondents, $60 \%$ of respondents preferred to invest in high rise apartment and condominium, $28.60 \%$ preferred terrace house, $2.90 \%$ preferred semi-detached house, $2.90 \%$ preferred detached house, and $5.70 \%$ preferred other types of residential property, respectively. Table 1 also showed that majority of respondents were male $(66.70 \%)$. In terms of age, $41 \%$ of the respondents were in the age of $25-35$, followed by the age of 35-45 (34.2\%), the age of under $25(16.2 \%)$, and the age of above $45(8.60 \%)$, respectively. Table 1 also showed the marital status of all respondents. $63.8 \%$ were single and $36.2 \%$ were married. There were total of $42.9 \%$ were working executive, $34.3 \%$ were professional, and $22.8 \%$ were under other types of jobs. The results in Table 1 showed that higher education and income increase the likelihood of becoming an investor in property investment. 
Table 1: Respondents' characteristics

\begin{tabular}{|c|c|c|}
\hline & Frequency & Percentage \\
\hline \multicolumn{3}{|c|}{ What types of property do you invest in? } \\
\hline High rise & 63 & 60.0 \\
\hline Terrace & 30 & 28.6 \\
\hline Semi-detached & 3 & 2.9 \\
\hline Detached & 3 & 2.9 \\
\hline Others & 6 & 5.7 \\
\hline \multicolumn{3}{|l|}{ Gender } \\
\hline Males & 70 & 66.7 \\
\hline Females & 35 & 33.3 \\
\hline \multicolumn{3}{|l|}{ Age } \\
\hline Under 25 & 17 & 16.2 \\
\hline $25-35$ & 43 & 41.0 \\
\hline $35-45$ & 36 & 34.2 \\
\hline 45 Above & 9 & 8.6 \\
\hline \multicolumn{3}{|l|}{ Marital status } \\
\hline Single & 67 & 63.8 \\
\hline Married & 38 & 36.2 \\
\hline \multicolumn{3}{|l|}{ Profession } \\
\hline Executive & 45 & 42.9 \\
\hline Professional & 36 & 34.3 \\
\hline Others & 24 & 22.8 \\
\hline \multicolumn{3}{|l|}{ Education } \\
\hline Secondary level & 4 & 3.8 \\
\hline Undergraduate & 81 & 77.14 \\
\hline Postgraduate & 20 & 19.06 \\
\hline \multicolumn{3}{|c|}{ Monthly Income (Malaysian Ringgit) } \\
\hline Under $R M 4,000$ & 30 & 20.0 \\
\hline$R M 4,000-R M 8,000$ & 53 & 50.5 \\
\hline Above $R M 8,000$ & 22 & 29.5 \\
\hline
\end{tabular}

\section{FACTOR ANALYSIS AND RELIABILITY TEST}

As shown in Table 2, five factors have been extracted using Principal Axis factoring with the eigenvalues more than 1 . The Varimax rotation methods with the eigenvalues greater than 1 were used to sort all questions. Questions that had factor loading of less than 0.4 has been excluded for further analysis. All five factors have a cumulative variance of $74.658 \%$. First, second, third, fourth and fifth factors explained $30.945 \%, 18.096 \%, 10.758 \%, 8.115 \%$ and $6.744 \%$ of the total variance, respectively. The Cronbach's coefficient alphas of all individual constructs were between 0.723 and 0.890; therefore, all constructs were considered reliable. 
Table 2: Factor analysis

\begin{tabular}{|c|c|c|c|c|c|}
\hline & \multicolumn{5}{|c|}{ Factors } \\
\hline & $F 1$ & $F 2$ & $F 3$ & $F 4$ & $F 5$ \\
\hline \multicolumn{6}{|l|}{ Locational Factors } \\
\hline $\begin{array}{l}\text { L1: I would consider the presence of shops when I invest } \\
\text { in a residential property. }\end{array}$ & .879 & & & & \\
\hline $\begin{array}{l}\text { L2: I would consider the availability of retail centers } \\
\text { when I invest in a residential property. }\end{array}$ & .836 & & & & \\
\hline $\begin{array}{l}\text { L3: I would consider the presence of public } \\
\text { infrastructures when making a decision to invest in a } \\
\text { residential property. }\end{array}$ & .818 & & & & \\
\hline $\begin{array}{l}\text { L4: I would consider the presence of schools when I } \\
\text { invest in a residential property. }\end{array}$ & .796 & & & & \\
\hline $\begin{array}{l}\text { L5: I would consider the distance travelled to work when } \\
\text { I invest in a residential property. }\end{array}$ & .686 & & & & \\
\hline \multicolumn{6}{|l|}{ Financial Factors } \\
\hline $\begin{array}{l}\text { F1: I would consider the effects of Real Property Gains } \\
\text { Tax (RPGT) when I make a decision to invest in a } \\
\text { residential property. }\end{array}$ & & .808 & & & \\
\hline $\begin{array}{l}\text { F2: I would consider the Developer Interest Bearing } \\
\text { Scheme (DIBS) given by developers when I make a } \\
\text { decision to invest in a residential property. }\end{array}$ & & .801 & & & \\
\hline $\begin{array}{l}\text { F3: I would consider the Base Lending Rate (BLR) when } \\
\text { I make a decision to invest in a residential property. }\end{array}$ & & .752 & & & \\
\hline $\begin{array}{l}\text { F4: I would consider the importance of Mortgage Loan } \\
\text { to Value Ratio (LTV) before making a decision to invest } \\
\text { in a residential property. }\end{array}$ & & .646 & & & \\
\hline $\begin{array}{l}\text { F5: I would consider the property cooling measures set } \\
\text { by the government when I make a decision to invest in a } \\
\text { residential property. }\end{array}$ & & .645 & & & \\
\hline \multicolumn{6}{|l|}{ Structural Attributes of Housing } \\
\hline $\begin{array}{l}\text { S1: I would consider the size of the living area or dining } \\
\text { area when making a decision to invest in the residential } \\
\text { property. }\end{array}$ & & & .894 & & \\
\hline $\begin{array}{l}\text { S2: I would consider the number of bathrooms when } \\
\text { making a decision to invest in a residential property. }\end{array}$ & & & .890 & & \\
\hline $\begin{array}{l}\text { S3: I would consider the number of rooms when making } \\
\text { a decision to invest in a residential property. }\end{array}$ & & & .774 & & \\
\hline $\begin{array}{l}\text { S4: I would consider the internal and external structure } \\
\text { of a house when I invest in a residential property. }\end{array}$ & & & .670 & & \\
\hline \multicolumn{6}{|l|}{ Neighborhood Factors } \\
\hline $\begin{array}{l}\text { N1: I would consider the level of crime rate when making } \\
\text { a decision to invest in a residential property. }\end{array}$ & & & & .859 & \\
\hline $\begin{array}{l}\text { N2: I would consider the safety of the neighborhood when } \\
\text { making a decision to invest in a residential property. }\end{array}$ & & & & .782 & \\
\hline $\begin{array}{l}\text { N3: I would consider the level of pollutants in the air } \\
\text { when making a decision to invest in a residential } \\
\text { property. }\end{array}$ & & & & .699 & \\
\hline \multicolumn{6}{|l|}{ Motivation of Property Investment } \\
\hline $\begin{array}{l}\text { M1: I invest in a property because it gives an attractive } \\
\text { financial return. }\end{array}$ & & & & & .903 \\
\hline $\begin{array}{l}\text { M2: I invest in a property because it is an investment } \\
\text { instrument to hedge against inflation. }\end{array}$ & & & & & .759 \\
\hline Cronbach's alpha & 0.890 & 0.850 & 0.868 & 0.732 & 0.723 \\
\hline Eigenvalues & 5.880 & 3.438 & 2.044 & 1.542 & 1.281 \\
\hline \% of Variance & 30.945 & 18.096 & 10.758 & 8.115 & 6.744 \\
\hline Cumulative \% & 30.945 & 49.041 & 59.799 & 67.914 & 74.658 \\
\hline
\end{tabular}


The first factor consisted of five (5) survey items relating to locational attributes. The Cronbach's alpha value of 0.890 suggested these five (5) survey items are one-dimensional and may be combined in a scale. The eigenvalue for this factor is 5.880. Of five (5) survey items, the item "I would consider the presence of shops when I invest in a residential property" was the most important statement with a loading of 0.879 . The next significant item was "I would consider the availability of retail centers when I invest in a residential property" with a loading of 0.836 . This was then followed by the item "I would consider the presence of public infrastructures when making a decision to invest in a residential property" with a factor loading of 0.818 . The last two items were "I would consider the presence of schools when I invest in a residential property" and "I would consider the distance travelled to work when I invest in a residential property" with loadings of 0.796 and 0.686 , respectively. In this survey, investors generally agree that well located properties will show good returns should the location become more sought after.

The second factor was referred to as financial factors, consisted of "I would consider the effects of Real Property Gains Tax (RPGT) when I make a decision to invest in a residential property", "I would consider the Developer Interest Bearing Scheme (DIBS) given by developers when I make a decision to invest in a residential property", "I would consider the Base Lending Rate (BLR) when I make a decision to invest in a residential property", "I would consider the importance of Mortgage Loan to Value Ratio (LTV) before making a decision to invest in a residential property" and "I would consider the property cooling measures set by the government when I make a decision to invest in a residential property" with factor loadings of $0.808,0.801,0.752,0.646$, and 0.645 , respectively. The eigenvalue for the second factor was 3.438 and the Cronbach's value of this construct was considered reliable (0.850). As shown in this survey, property financing is the main consideration that turns many property investors away from the investment. The recent upward revision of real property gains tax and stricter lending regulations by the bank may be a worrying trend for property investors as the effect of government efforts to curb speculation may soften the volume of primary and secondary property market transactions.

The third factor consisted four (4) survey items regarding structural attributes of housing (Cronbach's alpha $=0.868$ ). As expected, the size of the living area or diving area (a loading 0.894), the number of bathrooms (a loading of 0.890), the number of rooms (a loading of 0.774) and the internal and external structure of a house (a loading of 0.670) were common structure attributes of housing when considering a property to invest.

Factor 4 can be referred as neighborhood factors (Cronbach's alpha $=0.732$ ). This factor consisted of three (3) survey items, namely "I would consider the level of crime rate when making a decision to invest in a residential property", "I would consider the safety aspect when making a decision to invest in a residential property", and "I would consider the level of pollutants in the air when making a decision to invest in a residential property" with factor loadings of 0.859, 0782 and 0.699 , respectively.

The last construct was the motivation of investing in residential property, consisting of two (2) questions with Cronbach's alpha value of 0.723 . The item "I invest in a property because it gives an attractive financial return" has a higher factor loading of 0.903 and followed by "I invest in a property because it is an investment instrument to hedge against inflation" with a factor loading of 0.759. Similar to the finding of Tan (2008), financial motivation has been an important reason in the explanation of property investment. 


\section{REGRESSION ANALYSIS}

In the following discussion, regression analysis was performed to identify the relationships between location, neighborhood, structural, and financial attributes towards the investment motivation. Table 3 indicated the results of the conducted regression analysis. The F value (4.521), Sig 0.002 indicated the significance of the model at 5\% intervals. $\mathrm{R}$ square and adjusted $\mathrm{R}$ square indicated that this regression model could be explained $15.3 \%$ and $11.9 \%$, respectively by the considered independent variables. As pointed by Bedeian and Mossholder (1994), this relatively low $\mathrm{R}$ squared value is really common with cross-sectional data in social sciences.

Table 3: Regression results

\begin{tabular}{|c|c|c|c|c|}
\hline \multirow{2}{*}{} & \multicolumn{4}{|c|}{ Equation } \\
\cline { 2 - 5 } & $\boldsymbol{B}$ & Std Error & $\boldsymbol{t}$ & Sig. \\
\hline Constant & 2.225 & 0.668 & 3.330 & 0.001 \\
\hline Locational $(L)$ & 0.792 & 0.352 & 2.250 & 0.026 \\
\hline Neighborhood $(N)$ & 0.030 & 0.101 & 0.295 & 0.769 \\
\hline Structural $(S)$ & 0.215 & 0.094 & 2.285 & 0.024 \\
\hline Financial $(F)$ & 0.336 & 0.129 & 2.605 & 0.011 \\
\hline$R$ & 0.391 & & & \\
\hline$R^{2}$ & 0.153 & & & \\
\hline Adjusted $R^{2}$ & 0.119 & & & \\
\hline Std error & 0.120 & & & \\
\hline$F$ & 4.521 & & & \\
\hline Sig & 0.002 & & & \\
\hline
\end{tabular}

According to the survey, locational factor is deemed to be the most important factor on residential property investment decisions $(\beta=0.792)$. This study showed that investors will look into some consideration of locational attributes when it comes to investors making a purchase decision, for instance access to public infrastructure, distance to work and school, and availability of retail centres. Clark et al. (2006) noted that an easy access to public infrastructure will bring convenience and increase housing value. As pointed by Cheah and Tan (2012), short distance to work will result in low transportation costs. Moreover, Youqin and Chengdong (2011) mentioned that households with children would consider moving their house closer to the school. Thus, by staying closer to the workplace and school will bring about time saving. In addition, the availability of retail centers and shops will provide convenience to households as grocery buying is an essential part of living of a household (Cheah \& Tan, 2012). Also, getting a well-located property will ensure that the property gets tenanted faster and remains occupied the most, at the best rental. The well located property will show good returns should the location become more sought after (Tan, 2012b).

Based on this survey, the next important factor for investors to look highly upon is financial factor $(\beta=0.336)$. It is because property investment has the largest initial capital requirements compared to other investment vehicles, such as fixed income security and shares. It also has the lowest liquidity among all investment vehicles as they are many procedures for the sale and purchase of property; therefore, easy financing schemes such as low BLR and DIBS matter to property investors. Investors only favor real estate as an investment if they are able to secure higher financing, lower transaction costs and capital requirements in owning the property (Tan, 2010b). In view of the government's 
efforts to reign in speculation in the property market, Malaysian regulators have instructed banks to tighten property lending by raising the loan-to-value ratio to $70 \%$ on the third mortgage and by removing the developer interest bearing scheme (DIBS). The removal of DIBS and high loan-to-value ratio will make an impact on property investment due to the occurrence of high down payment in acquiring the property (The Sun Daily, 2013). Additionally, the RPGT in Malaysia has reached new record high in 2014 (Hann, 2014). Many investors in the survey pointed out that the RPGT hike during the recent announcement of 2014 Budget would not only greatly influence the profitability of an investment but also cause unnecessary uncertainties in the investment environment.

The results in Table 3 revealed that structural attributes affect investment decisions upon purchasing a residential property. This finding is consistent with home ownership studies, for instance, the study by Hurtubia et al. (2010) who revealed that the number of room or bathrooms in a house is an important feature to be considered by households. Besides that, Hurtubia et al. (2010) stated that households comprising of one to three persons will typically prefer a small number of spacious rooms and on the other hand, larger families will rather opt for large number of rooms. As for property investment, investors generally gauge the property according to the build-up, room size, and number of bathrooms. This is because investors would have to calculate their ability to take down loans as different built-ups have different prices. Also, they gauge the markets in terms of price/psf. The saleability of their properties fully depends on the size of the property. In view of high property prices in the Klang Valley and land scarcity, small properties such as apartments, flat and townhouses have always been more popular among tenants. As a result, housing developers would have to be carefully thought of design and layout of the house when selling the property to investors.

However, neighborhood attributes had no effects in investment decisions upon purchasing a residential property, all other things being equal. This study shows that environmental quality is not a factor for investors to look into before purchasing a property to invest in. In contrast, the home ownership study by Yusuf and Resosudarmo (2009) clearly demonstrated the importance of air quality on households' home ownership preferences. Additionally, this study's finding is not consistent with Wang and $\mathrm{Li}$ (2006) who stated that households will place concern on crime and other security problems in neighborhood when making decision for home ownership. It could be due to the fact that investors who buy the property do not necessarily stay in that area. They are hoping for more of the capital gains as well as monthly rental returns. Therefore, as long as the property gives them either one or both of these windfalls, it would still be a good investment regardless of neighborhood conditions.

\section{CONCLUSION AND RECOMMENDATION}

Becoming a property investor is a great way to earn either short or long term financial returns. Finding the right property to invest requires a lot of knowledge and without it the investment might cost investors dearly. According this survey, locational, financial and structural factors prove to be significant at $5 \%$ with p-value of $0.026,0.011$ and 0.024 , respectively; therefore, these significant factors should be taken into the consideration as far as investors are concerned. However, investors do not really consider the neighborhood of the property they purchase as long as they do not have an intention to stay in these properties.

Although the government's various cooling measures to curb speculation would have a considerable impact on the property market in the short run, these measures are essential to create a healthier property market led more by fundamentals. Malaysia's property market is a significant contributor to the country's gross domestic product, it is important to promote a stable property market. In this 
regard, property investment decisions should not always be made just on the basis of profitability, but should ensure that the property market remains healthy and sustainable.

Even though properties will bring in financial gain, it is not advisable that investors buy what they cannot afford. It is important to stay within the budget to make sure that they can pay for the monthly payments even without tenants. It is good advice for investors to not over gear themselves in borrowings as there is a need to consider the financing for both the acquisition and the holding of the property. Given the high rate of RPGT, investors may have to consider changing their investment strategy and avoid flipping them within a short period as the higher RPGT rate would negatively impact investors' returns.

Despite the interesting results, this paper contains several limitations that may hinder the contribution of this study. Firstly, the sample of the study is considered relatively small to represent the whole population of Malaysia as the analysis was based on 105 respondents which may not be sufficient to cover all range of investors in terms of various age, education levels and income groups. Secondly, further research may consider broader range of property investment determinants, such as reputation and quality of developers in view of relatively low R-square. Finally, the analysis of the study's result is limited to Greater Kuala Lumpur area. Thus, it would be recommended for future research to extend the research geographically to get a more comprehensive view on property investment.

\section{REFERENCES}

Arimah, B.C. (1992). An empirical analysis of the demand for housing attributes in a third world city. Land Economics, 68, 366-379.

Asiedu, A. B., \& Arku, G. (2009). The rise of gated housing estate in Ghana: Empirical insights from three communities in metropolitan Accra. Journal of Housing and the Built Environment, 24(3), $227-247$.

Bedeian, A. G., \& Mossholder, K. W. (1994). Simple question, not so simple answer: Interpreting interaction terms in moderated multiple regression. Journal of Management, 20(1), $159-165$.

Blakely, E., \& Snyder, M. G. (1998). Separate places: Crime and security in gated communities. In M. Felson \& R. B. Reiser (Eds.) Reducing crime through real estate development and management (53 - 70). Washington, D. C.: Urban Land Institute.

Case, K. E., \& Shiller, R. J. (1988). The behavior of home buyers in boom and post-boom markets. New England Economic Review, November/December, 29-46.

Chapman, D. W., \& Lombard, J. R. (2006). Determinants of neighborhood satisfaction on fee-based gated and non-gated communities. Urban Affair Review, 41, 769-799.

Chin, C. (2013). Young professionals struggle to own property. The Star Online. Retrieved July 14, from, http://www.thestar.com.my/News/Nation/2013/07/14/Dad-dont-kick-me-out-yet.aspx/

Cheah Y. Y., \& Tan, T. H. (2012). Locational, neighborhood, structural and socio-cultural attributes of housing in homeownership decisions. Proceeding for $6^{\text {th }}$ International Real estate Research Symposium (IRERS) 2012, Globalization of Real Estate: Transformation and Opportunities, National Institute of Valuation (INSPEN). Selangor, Malaysia: Ministry of Finance.

Choguill, C.L. (2008). Developing sustainable neighborhoods. Habitat International, 32, 41-8.

Clark, W., Deurloo, M., \& Dieleman, F. (2006). Residential mobility and neighborhood outcomes. Housing Studies, 21(3), 323 - 342.

Daly, J., Gronow, S., Jenkins, D., \& Plimmer, F. (2003). Consumer behaviour in the valuation of residential property: A comparative study in the UK, Ireland and Australia. Property Management, 21(5), 295-314.

Elder, H. W., \& Zumpano, L. V. (1991). Tenure choice, housing demand and residential location. Journal of Real Estate Research, 6(3), 341 - 356. 
Fama, E.F., \& Schwert, G.W. (1977). Asset returns and inflation. Journal of Financial Economics, $5,115-164$.

Fierro, K., Fullerton, T., \& Donuan-Callejo, K. (2009). Housing attributes preference in a northern Mexico metropolitan economy. Atlantic Economic Journal, 37, 159- 172.

Haughwout, A., Lee, D., Tracy, J., \& Klaauw, W. V. D. (2011). Real estate investors, the leverage cycle, and the housing market crisis. Federal Reserve Bank of New York. Staff Report no. 514. Retrieve from, http://www.econstor.eu/bitstream/10419/60965/1/ 668533382.pdf

Hann, L. (2014). Malaysia Budget 2014 review - A guide to property tax policy changes and GST. Malaysian Digest. Retrieved from, http://www.malaysiandigest.com/features/485628malaysia-budget-2014-review-a-guide-to-property-tax-policy-changes-and-gst.html.

Hunter, A. (1985). Private, parochial, and public social orders: The problem with crime and incivility in urban communities. In G. D. Suttles \& M. N. Zald (Eds) The Challenge of Social Control: Citizenship and Institution Building in Modern Society (230 - 242). Norwood, NJ: Aldex.

Hurtubia, B., Gallay, O., \& Bielaire, M. (2010). Attributes of household, locations and real estate for land use modeling. Sustain City Working Paper, 2.7. Lausanne: EPFL.

Hutchison, N.E. (1994). Housing as an investment. Journal of Property Finance, 5(2), 47-61.

Karsten, L. (2007). Housing as a way of life: Towards an understanding of middle-class families' preference for an urban residential location. Housing Studies, 22(1), 83-98.

Kauko, T. (2003). Residential property value and locational externalities- On the complementarity and substitutability of approaches. Journal of Property Investment and Finance, 21(3), 250268.

Kauko, T. (2007). An analysis of housing location attributes in the inner city of Budapest, Hungary, using expert judgment, International Journal of Strategic Property Management, 11, 209 225.

Kohler, M. J. (2013). Why you should be investing your money in real estate. Entrepreneur. September. Retrieved from: http://www.entrepreneur.com/article/228506.

Laakso, S., \& Loikkanen, H.A. (1995). Finnish homes - Through passages or traps. Real Estate Economics, 23, 475-95.

Lang, R.E., \& LeFurgy, J. (2007). Boomburbs: The rise of America's accidental cities. Washington, D.C: Brookings Institution Press.

Levine, J. (1998). Rethinking accessibility and jobs-housing balance. Journal of the American Planning Association, 64, 133- 149.

Lim, C.Y. (2013) RPGT can curb speculation in long run. Business Times. Retrieved from, http://www.btimes.com.my/Current_News/BTIMES/articles/20130913120146/2013091312 0146.pdf

Mira, S. (2013) Malaysian properties take on the world. News Straits Times. Retrieved September 13, 2013 from http://www.nst.com.my/red/cover-story-malaysian-properties-take-on-theworld-1.355013

Reed, R., \& Mills, A. (2006). Identifying the drivers behind housing preferences of first-time owners. Property Management, 25(3), 225-241.

Sanchez, T. W., Lang, R. E., \& Dhavale, D. M. (2005). Security versus status? A first look at the census's gated community data. Journal of Planning Literature and Education, 24(1), 281 291.

Seelig, T. (2009). What motivates households to invest in the private rental market? Australian Housing and Research Institute, 115 June.

Tan, T. H. (2008). Determinants of homeownership in Malaysia. Habitat International, 32 (2), 318 335.

Tan, T. H. (2009). Homeowning motivation in Malaysia. Journal of Accounting-Business and Management, 16(1), 93-112. 
Tan, T. H. (2010a). The effect of housing characteristics on neighborhood stability of homeownership. International Journal of Business and Emerging Market, 2(3), 286 - 304.

Tan, T. H. (2010b). Base lending rate and housing prices: Their impacts on residential housing activities in Malaysia. Journal of Global Business and Economics, 1(1), 1- 14.

Tan, T. H. (2011a). Measuring the willingness to pay for houses in a sustainable neighborhood. The International Journal of Environmental, Cultural, Economic \& Social Sustainability, 7, 1 12.

Tan, T. H. (2011b). Neighborhood preferences of house buyers: The case of Klang Valley, Malaysia. International Journal of Housing Markets and Analysis, 4(1), 58-69.

Tan, T. H. (2012a). Housing satisfaction in medium- and high-cost housing: The case of greater Kuala Lumpur, Malaysia. Habitat International, 36(1), 108 - 116.

Tan, T. H. (2012b). Meeting first-time buyers' housing needs and preferences in greater Kuala Lumpur. Cities, 29(6), 389-396.

Tan, T. H., \& Phang S. N. (2014). Growth and Livability: The case of greater Kuala Lumpur. In P.A. Lee., \& B.D. Sanchita. (Eds.) Malaysia's Social-Economic Transformation: Ideas for the Next Decade. Singapore: Institute of Southeast Asian Studies.

The Edge (2013). Malaysia's property market holds promise for foreigners. Retrieved from, http://www.theedgemalaysia.com/in-the-financial-daily/232658-malaysias-property-marketholds-promise-for-foreigners.html.

The Sun Daily (2013). Property developers express mixed views on Budget 2014. Retrieved from, http://www.thesundaily.my/news/865996.

Tiwari, P., \& Parikh, J. (1998). Affordability, housing demand and housing policy in Urban India. Urban Studies, 35, 2111-2129.

Tse, R.Y.C., \& Love, P.E.D. (2000). Measuring residential property values in Hong Kong, Property Management, 18, 366-374.

Tu, Y., \& Goldfinch, J. (1996). A two-stage housing choice forecasting model, Urban Studies, 33, $517-537$.

Wang, D., \& Li, S. (2006). Socio-economic differentials and stated housing preferences in Guangzhou, China. Habitat International, 30, 305 - 326.

Wilhelmsson, M. (2000). The impact of traffic noise on the value of single-family houses. Journal of Environmental Planning \& Management, 43(6), 799-815.

Yoong, Y. (2012). MM2H sees higher participation. New Straits Time, May 18. Retrieved from, http://www.nst.com.my/red/mm2h-sees-higher-participation-1.85124.

Youqin, H., \& Chengdong, Y. (2011). Second home ownership in transitional urban China. Housing Studies, 26(3), 423 - 447.

Yusuf, A., \& Resosudarmo, B. (2009). Does clean air matter in developing countries' megacities? A hedonic price analysis of the Jakarta housing market. Indonesia' Ecological Economics, 68, $1398-1407$. 